\title{
Hygroscopic behavior of buriti (Mauritia flexuosa) fruit
}

\author{
Comportamento higroscópico do buriti (Mauritia flexuosa)
}

\author{
Wellington dos Santos MELO ${ }^{1}$, Rosinelson da Silva PENA ${ }^{2 *}$, \\ Antonio Manoel da Cruz RODRIGUES ${ }^{2}$, Luiza Helena Meller da SILVA ${ }^{2}$
}

\begin{abstract}
The objective of this study was to perform an analysis of the characterization of buriti fruit (Mauritia flexuosa). Each part of the fruit (peel, pulp, and fibrous part) was analyzed and their hygroscopic behavior was evaluated to establish the drying and storage conditions. Adsorption and desorption isotherms were obtained at $25^{\circ} \mathrm{C}$ to the monolayer value was estimated, and the application of the Halsey, Handerson, Kuhn, Mizrahi, Oswin, Smith, BET, and GAB models was evaluated to the prediction of the isotherms. The fruit pulp was classified as rich in high quality oil, and like the peel and the fibrous part, it was also considered as rich in dietary fiber. The isotherms of the fruit parts were classified as type II, and their microbiological stability $\left(\mathrm{a}_{\mathrm{w}}<0.6\right)$ can be maintained at $25^{\circ} \mathrm{C}$ if the moisture content is lower than $8.5,7.3$, and $11.0 \mathrm{~g}$ $\mathrm{H}_{2} \mathrm{O} .100 \mathrm{~g}^{-1}$ of dry matter (d.m.), respectively. The hygroscopic behavior showed that in order to ensure stability, the fruit parts should be packaged with low water vapor permeability. The monolayer demonstrated that the peel, pulp, and the fibrous part cannot be dried under moisture content lower than 5.9, 5.0, and $6.4 \mathrm{~g} \mathrm{H}_{2} \mathrm{O} .100 \mathrm{~g}^{-1} \mathrm{~d} . \mathrm{m}$., respectively. GAB was the most adequate model to describe their isotherms. Keywords: buriti; Mauritia flexuosa; drying; storage; isotherm.
\end{abstract}

\section{Resumo}

Foram caracterizadas a casca, a polpa e a parte fibrosa do buriti (Mauritia flexuosa) e avaliados os seus comportamentos higroscópicos, visando estabelecer condições de secagem e de armazenamento para os produtos. Foram obtidas isotermas de adsorção e dessorção de umidade a $25^{\circ} \mathrm{C}$, determinado o valor da monocamada e avaliada a aplicabilidade dos modelos: Halsey, Handerson, Kuhn, Mizrahi, Oswin, Smith, BET e GAB, na predição das isotermas. A polpa foi classificada como rica em óleo de alta qualidade e juntamente com a casca e a parte fibrosa como ricas em fibra alimentar. As isotermas dos produtos foram classificadas como do tipo II e suas estabilidades microbiológicas a $25^{\circ} \mathrm{C}$ asseguradas quando apresentarem umidade inferior a 8,5, 7,3 e 11,0 g $\mathrm{gH}_{2} \mathrm{O} .100 \mathrm{~g}^{-1} \mathrm{de}$ base seca, respectivamente. Segundo a avaliação, os produtos serão mais bem conservados, se acondicionados em embalagens com baixa permeabilidade ao vapor de água, e os valores da monocamada indicaram que a casca, a polpa e a parte fibrosa não devem ser secas a umidades inferiores a 5,9, 5,0 e 6,4 $\mathrm{gH}_{2} \mathrm{O}_{10} 100 \mathrm{~g}^{-1} \mathrm{~b} . \mathrm{s}_{\text {. }}$ respectivamente. $\mathrm{O}$ modelo de $\mathrm{GAB}$ foi o que melhor descreveu as isotermas dos produtos.

Palavras-chave: buriti; Mauritia flexuosa; secagem; armazenamento; isoterma.

\section{Introduction}

Among the plant species in the Amazon region, are the palm trees, whose fruits are abundant alternative sources of vegetable oil with high nutritional value. Buriti (Mauritia flexuosa) stands out as a species inhabiting acid and low fertility soils. It is found in Brazil (GAZEL-FILHO; LIMA, 2001), where it is exceptionally well-suited for fresh juice or candy consumption in the North and Northeast regions of the country.

The oil extracted from the buriti fruit is of great interest because of its physical and chemical characteristics. Studies conducted by Albuquerque et al. (2003) indicated that this oil has high concentrations of carotenoids, tocopherols, and oleic and palmitic fatty acids. The growth of buriti industrialization for oil extraction has contributed to the generation of large quantities of residue: peel, fibers, and nuts.

The fruit and vegetable residues discarded by the industry are generally used in commercial products such as animal feed or fertilizer. However, they could be used as alternative sources of nutrients in low cost foods. Therefore, it is necessary to consider new alternatives to the use of such residue in order to characterize and identify their potential. Buriti's fiber and peel, rich in pigments, are alternatives to the food and pharmaceutical industry.

Most of the processes of oil extraction, whether physical or chemical, require preliminary drying of raw materials since the presence of water hinders the extraction process. The main product of the food, cosmetics, and pharmaceutical industries is buriti oil, rich in vitamins and fatty acids. Therefore, studies are needed to establish appropriate conditions for the drying and storage of the pulp used in the oil extraction and the residue from the extraction process, such as the peel and the fibrous part, which are good sources of dietary fiber. According to Ferreira (2010), for the extraction of $45 \mathrm{~kg}$ of buriti oil, 1,000 kg of fresh fruits are needed.

\section{Received 9/3/2010}

Accepted 4/9/2010 (004715)

${ }^{1}$ Master in Food Science and Technology, Federal University of Pará - UFPA, Belém, PA, Brazil

${ }^{2}$ Faculty of Food Engineering -FEA, Institute of Technology - ITEC, Federal University of Pará - UFPA, Augusto Corrêa Street, 1, Guamá, CEP 66075-900, Belém, PA, Brazil, e-mail:rspena@ufpa.br

${ }^{*}$ Corresponding author 
Adsorption and desorption isotherms can provide important information for the design of the drying process, selection of packages, and establishment of food storage conditions. The isotherms are obtained from adsorption (moisture gain) and desorption (moisture loss) data, but they can be predicted using mathematical models, widely reported in the literature (AVIARAA et al., 2006; ASSUNÇÃO; PENA, 2007; FURMANIAK et al., 2007; PENG et al., 2007).

Given the little amount of information available and the need to present alternatives to the commercial use of the buriti fruit and its residues, this study aimed to characterize the peel, pulp, and the fibrous part of the fruit, as well as to evaluate their adsorption and desorption isotherms to establish drying and storage conditions for them.

\section{Material and methods}

\subsection{Raw material}

Buriti fruits were collected from trees located in the river basin in the city of Abaetetuba (Pará, Brazil). They were selected, washed, and sanitized with chlorine solution $\left(5 \mathrm{mg} \cdot \mathrm{L}^{-1}\right)$ for 30 minutes. Fruits that presented visual defects, mechanical damage, and attack by fungi and wood pests were discarded. The others were subjected to autoclaving for 30 minutes to enable the separation of parts (peel, pulp, fibrous part, and nut) (Figure 1) with a steel knife. A sample of fresh pulp was collected for characterization.

The peel, pulp, and fibrous part of the fruit were dried in a forced-air tray dryer for 24 hours at $60^{\circ} \mathrm{C}$. The products were ground in a knife mill and were classified as flour, according to the Brazilian legislation (BRAZIL, 2005). The samples were packed in plastic bags and storage under controlled temperature $\left(\approx 5^{\circ} \mathrm{C}\right)$.

\subsection{Physical and physicochemical characterization of buriti}

A great number of fruits were used for the physical characterization, from which 132 fruits were randomly selected and subjected to autoclaving for 30 minutes. Next, the parts (peel, pulp, fibrous part, and nut) were separated using a steel knife, and weighed in a semi-analytical balance.

The physicochemical characterization was performed in the fresh pulp, peel, and fiber flours of buriti. The following tests
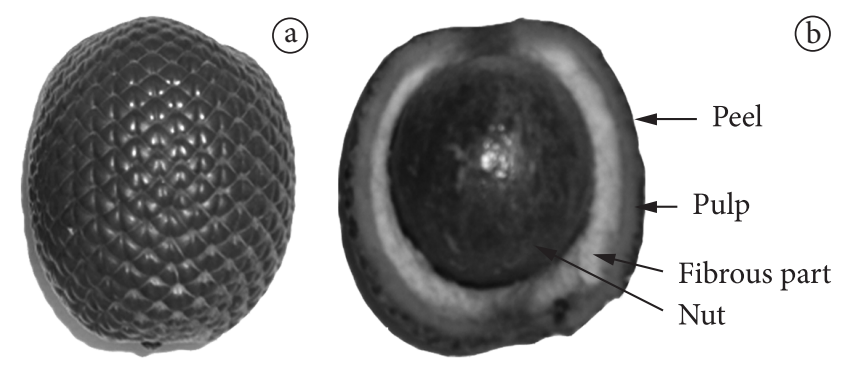

Figure 1. Buriti: a) whole fruit, and b) longitudinal section of fruit. were performed according to the official methods of analysis for fruits (ASSOCIATION..., 1997; AMERICAN..., 2002): moisture content at $105{ }^{\circ} \mathrm{C}$, total protein by Kjedhal method using the conversion factor of 6.25 , ashes in a Mufla oven at $550{ }^{\circ} \mathrm{C}$, total fat by extraction with petroleum ether in a Soxhlet apparatus, and total and insoluble dietary fiber content by the enzymatic method. The soluble fiber content was determined by the difference between the total and insoluble fiber contents. The carbohydrates were determined by the difference from the other constituents, including dietary fiber. All analyses were performed in triplicate.

\subsection{The adsorption and desorption isotherms}

Adsorption and desorption isotherms were created for the peel and fibrous part flours and for the buriti pulp. To obtain the adsorption data, samples of the products, with approximately one gram, were weighed in an analytical balance (A\&D Company, Limited Model HR-200). The samples were then transferred to a vacuum desiccator containing silica gel and maintained at $25{ }^{\circ} \mathrm{C}$ for 24 hours for a complementary dehydration. In order to follow the water adsorption, the sample were redirected to another desiccator containing water under the sample platform of the desiccator and this set was maintained in a refrigerated stove at $25 \pm 1{ }^{\circ} \mathrm{C}$.

For obtaining the desorption data, the same adsorption samples were placed in the same desiccator with water, and the set was maintained at $25^{\circ} \mathrm{C}$ for 24 hours for highest hydration. Then the set was transferred to a desiccator containing silica gel and it was maintained in a refrigerated stove at $25 \pm 1{ }^{\circ} \mathrm{C}$.

For both processes, the sample (in replicate) were removed from the desiccators in different contact times (dynamic equilibrium). Differences in moisture content with time were evaluated by weighting the samples and measuring the water activity with a hygrometer (Aqualab 3TE, Decagon, Pullman, WA). This methodology was tested by Assunção and Pena (2007) and Silva, Silva and Pena (2008) and has been used by the food group at the Federal University of Pará with excellent reproducibility. During the tests, the samples were submitted to visual inspection to monitor perceptive changes such as: fluidity loss, darkness, and growth of fungi.

The moisture of the monolayer $\left(\mathrm{m}_{\mathrm{o}}\right)$ was determined by the BET linear equation (Equation 1) and using the Excel software for Windows 2007 (Microsoft Corporation, Redmond, WA).

$\frac{a_{w}}{\left(1-a_{w}\right) \cdot m}=\frac{1}{m_{o} \cdot C}+\frac{(C-1)}{m_{o} \cdot C} \cdot a_{w}$

where: $\mathbf{m}=$ moisture content $\left(\mathrm{g} \mathrm{H}_{2} \mathrm{O} .100 \mathrm{~g}^{-1} \mathrm{~d} . \mathrm{m}.\right)$; $\mathbf{a}_{\mathbf{w}}=$ water activity; $\mathbf{m}_{\mathbf{o}}=$ monolayer moisture content $\left(\mathrm{g} \mathrm{H}_{2} \mathrm{O} .100 \mathrm{~g}^{-1} \mathrm{~d}\right.$.m.); and $\mathbf{C}=$ constant related to the heat of sorption.

\subsection{Prediction of adsorption and desorption isotherms}

Eight mathematical models, six bi-parametric and two tri-parametric models (Table 1), were tested in the prediction of adsorption and desorption isotherms. Regression analysis was performed using the software Statistica for Windows 
7.0 (StatSoft Inc., Tulsa, OK, USA), using the LevenbergMarquardt estimation method and convergence criteria of $10^{-6}$. The parameters used to evaluate the adjustments were the coefficient of determination $\left(\mathrm{r}^{2}\right)$, the mean relative deviation modulus (P) (Equation 2), and the correlation between the dependent variable ( $\mathrm{Y}$, water activity or moisture content) and experimental $\left(\mathrm{Y}_{\text {exp }}\right)$ and predicted values $\left(\mathrm{Y}_{\text {pre }}\right)$. $\mathrm{P}$ values less than $10 \%$ were considered by Peng et al. (2007) as indicators of good fits to isotherms and were used as a reference in the adjustment analysis.

$P=\frac{100}{n} \sum_{i=1}^{n} \frac{\left|Y_{\exp }-Y_{p r e}\right|}{Y_{\exp }}$

Where: $\mathbf{Y}_{\text {exp }}$ and $\mathbf{Y}_{\text {pre }}$ are the experimental and predict dependent variables, respectively, and $\mathbf{n}$ is the number of observations.

\section{Results and discussion}

\subsection{Physical and physicochemical characterization of buriti}

The physical composition of buriti is shown in Table 2. It is observed that the fruit presents a high inedible/edible ratio, thereby contributing to the generation of a high volume of industrial residue, which can reach $80 \%$.

The date of the composition of the pulp, peel and fiber flours of buriti are presented in Table 3. The average moisture content found for the buriti pulp is accordance with that of other oleaginous fruit pulps such as palm, peach palm, and tucumã (CLEMENT; AGUIAR; ARKCOLL, 1998; GUEDES, 2006).

The buriti parts studied can be classified as rich in dietary fiber with high content of total fat, according to the Brazilian legislation (BRAZIL, 1998) that establishes the minimum values of these constituents as $6 \mathrm{~g} .100 \mathrm{~g}^{-1}$ and $3 \mathrm{~g} .100 \mathrm{~g}^{-1}$ (for solid foods), respectively.

With regard to dietary fiber, the insoluble fibers predominate in all fractions, and the soluble fibers accounted for $20 \%$ of the pulp. Still regarding the fibers, it is emphasized that they are also the main constituents in the three parts of the fruit. According to the classification, all parts studied are potential sources of dietary fiber and can be used in diets that require this constituent although none of them meets the recommendation of the soluble fiber/soluble fiber ratio for a good diet, which is 1:2 (FIGUEROLA et al., 2005).

The pulp presented the highest levels of total fat and protein, and its fat content is comparable to that of some commercially exploited oleaginous (DE ROSSO; MERCADANTE, 2007). It can be emphasized that $68 \%$ of total fat is composed of unsaturated fraction, which is in agreement with Silva et al. (2009), who determined the oleic acid (monounsaturated) as the main constituent of a mixture of industrial and nonindustrial buriti oil. This corroborates the classification of the fresh pulp, not only as fat source, but also as good quality fat for human consumption.
Table 1. Models used in the prediction of the adsorption and desorption isotherms.

\begin{tabular}{|c|c|}
\hline Model & Equation \\
\hline Halsey $^{1}$ & $m=\left[\frac{-a}{\ln a_{w}}\right]^{\frac{1}{b}}$ \\
\hline Handerson $^{1}$ & $m=\left[\frac{-\ln \left(1-a_{w}\right)}{a}\right]^{\frac{1}{b}}$ \\
\hline$K u h n^{1}$ & $m=-\frac{a}{\ln a_{w}}+b$ \\
\hline Mizrahi $^{1}$ & $a_{w}=\frac{a+m}{b+m}$ \\
\hline Oswin ${ }^{1}$ & $m=a\left[\frac{a_{w}}{1-a_{w}}\right]^{b}$ \\
\hline Smith ${ }^{1}$ & $m=a-b \cdot \ln \left(1-a_{w}\right)$ \\
\hline $\mathrm{BET}^{2}$ & $m=\frac{m_{o} \cdot c \cdot a_{w}}{1-a_{w}} \cdot\left(\frac{1-(n+1) \cdot a_{w}^{n}+n \cdot a_{w}^{n+1}}{1-(1-c) \cdot a_{w}-c \cdot a_{w}^{n+1}}\right)$ \\
\hline $\mathrm{GAB}^{3}$ & $m=\frac{m_{o} \cdot c \cdot k \cdot a_{w}}{\left[\left(1-k \cdot a_{w}\right) \cdot\left(1+(c-1) \cdot k \cdot a_{w}\right)\right]}$ \\
\hline
\end{tabular}

${ }^{1}$ Chirife and Iglesias (1978); ${ }^{2}$ Park and Nogueira (1992); ${ }^{3}$ Maroulis et al. (1988); $\mathrm{m}=$ moisture content; $\mathrm{m}_{\mathrm{o}}=$ monolayer moisture content; $\mathrm{a}_{\mathrm{w}}=$ water activity; $\mathrm{a}, \mathrm{b}, \mathrm{c}$, $\mathrm{k}=$ constants.

Table 2. Physical composition of buriti.

\begin{tabular}{cc}
\hline Constituent & Parts in 100 of fruit \\
\hline Peel & 19.0 \\
Pulp & 21.8 \\
Fibrous part & 16.1 \\
Nut & 43.1 \\
\hline
\end{tabular}

Table 3. Composition of the buriti fruit parts.

\begin{tabular}{cccc}
\hline Constituent & \multicolumn{3}{c}{ Buriti composition $\left(\mathrm{g} .100 \mathrm{~g}^{-1} \text { of product }\right)^{1}$} \\
\cline { 2 - 4 } & Peel flour & Fresh pulp & Fiber flour \\
\hline Moisture content & $7.47 \pm 0.07$ & $50.50 \pm 1.14$ & $6.24 \pm 0.08$ \\
Total fat & $6.32 \pm 0.41$ & $19.02 \pm 0.72$ & $7.06 \pm 0.05$ \\
Saturated & $\mathrm{ND}$ & 6.09 & $\mathrm{ND}$ \\
Unsaturated & $\mathrm{ND}$ & 12.93 & $\mathrm{ND}$ \\
Protein & $2.02 \pm 0.05$ & $3.74 \pm 0.02$ & $2.61 \pm 0.05$ \\
Ash & $3.21 \pm 0.01$ & $0.63 \pm 0.01$ & $4.38 \pm 0.01$ \\
Carbohydrate & 6.01 & 3.35 & 7.98 \\
Total dietary fiber & $74.97 \pm 1.70$ & $22.76 \pm 0.43$ & $71.73 \pm 0.64$ \\
Insoluble fiber & $74.01 \pm 0.54$ & $18.21 \pm 1.88$ & $70.62 \pm 0.37$ \\
Soluble fiber & 0.96 & 4.54 & 1.11 \\
\hline
\end{tabular}

${ }^{1}$ Mean \pm Standard deviation; ${ }^{2}$ Carbohydrates value, except dietary fiber; ND-Not determined. 

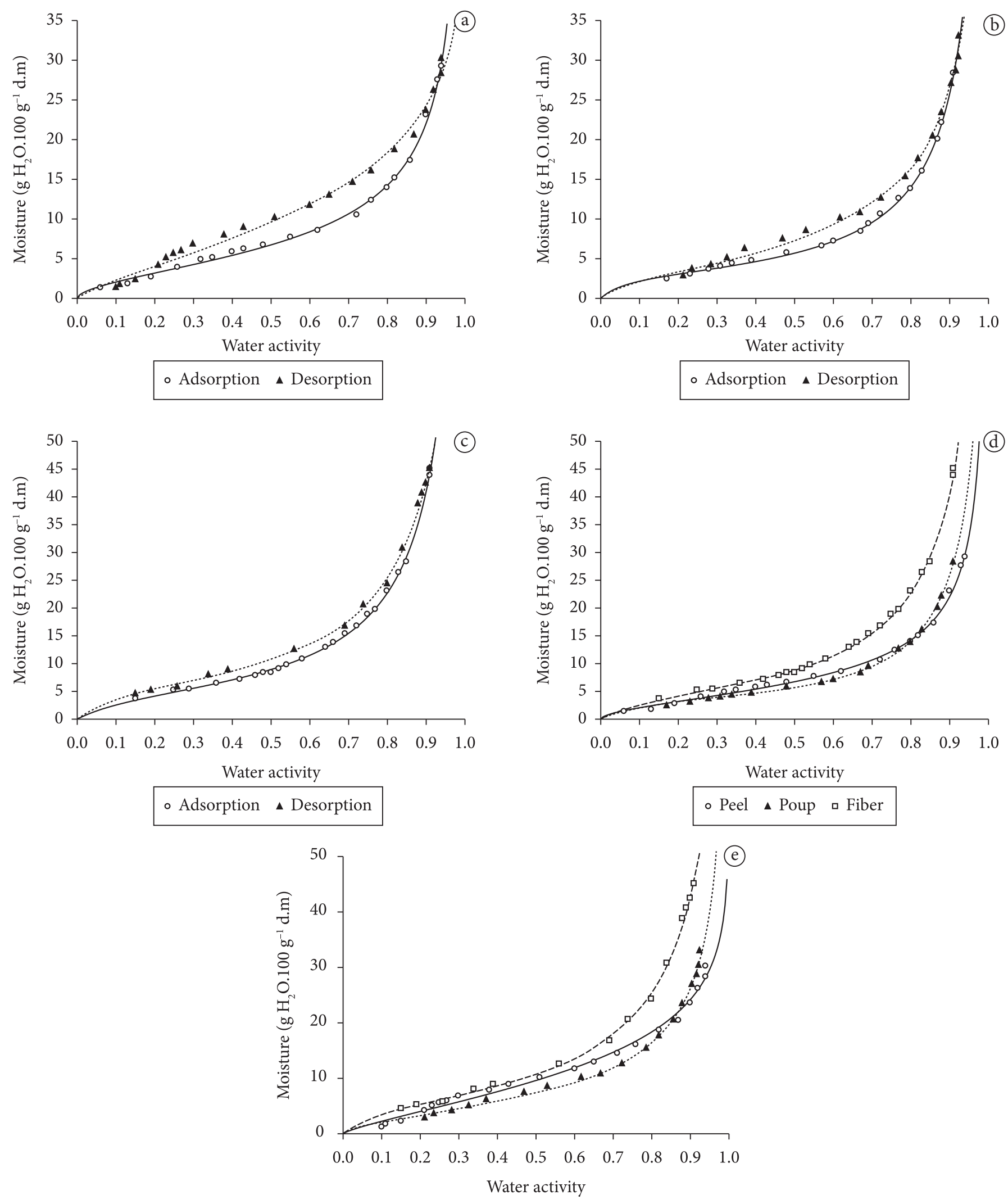

- Peel ^ Poup a Fiber

Figure 2. Isotherms of parts of buriti at $25^{\circ} \mathrm{C}$ : a) adsorption and desorption of the peel; b) adsorption and desorption of the pulp; c) adsorption and desorption of the fibrous part; $\mathrm{d}$ ) adsorption of the three parts; e) desorption of the three parts. 


\subsection{Moisture adsorption and desorption isotherms}

Figure 2 shows the moisture adsorption and desorption isotherms at $25^{\circ} \mathrm{C}$ for the three parts of the buriti fruit studied. All products showed type II isotherms, according to Salwin (1959) classification. This behavior is justified basically by high amounts of lipids and insoluble fibers in the products.

The adsorption data indicate that for the products (peel flour, pulp, and fiber flour) to have water activity $\left(\mathrm{a}_{\mathrm{w}}\right)$ greater than 0.6 , they must have moisture content higher than 8.5, 7.3 and $11.0 \mathrm{~g} \mathrm{H}_{2} \mathrm{O} .100 \mathrm{~g}^{-1}$ d.m., respectively, when stored at $25^{\circ} \mathrm{C}$. Scott (1957) established 0.6 as the limit of $\mathrm{a}_{\mathrm{w}}$ below which microbiological stability of the food is ensured. No visually perceptible change, such as loss of fluidity, darkness, or fungi growth was observed in the products studied during the adsorption and desorption tests.

In Figures 2d,e, it can be observed that there is a difference between the adsorption and desorption isotherms, characterizing the hysteresis effect, which extends over almost the entire $a_{w}$ range, being more pronounced in the region of capillary condensation (intermediate $a_{w}$ ). The effect was more pronounced for the buriti peel, which can be explained by the fact that it is the fraction that showed the lowest level of simple carbohydrates (soluble constituents) and the highest content of total fat and dietary fiber (in dry basis) with $98.7 \%$ of insoluble fiber.

According to the behavior of the adsorption isotherms, the three products studied showed to require more care when stored in an environment with relative humidity above $60 \%$, and in order to avoid the excessive gain of moisture, it is recommend the use of impermeable or low water vapor permeability package.

Based on the values of the monolayer $\left(\mathrm{m}_{\mathrm{o}}\right)$ for desorption of the peel, pulp, and fibrous part of buriti, 5.91, 4.97, and $6.40 \mathrm{~g}$ $\mathrm{H}_{2} \mathrm{O} .100 \mathrm{~g}^{-1}$ d.m., respectively, it is not recommended that the drying process reaches moisture levels lower than these.

Lowering the moisture content to below $\mathrm{m}_{\mathrm{o}}$, causes an exponential increase in the energy consumption involved in the drying process and in the lipid oxidation rate (SALWIN, 1963) to which these products are susceptible. Under the moisture contents reported, the three products presented $\mathrm{a}_{\mathrm{w}}$ less than 0.4 , which ensure their microbiological stability $\left(a_{w}<0.6\right)$.

\subsection{Prediction of the adsorption and desorption isotherms}

Based on the determination coefficient values $\left(\mathrm{r}^{2}\right)$ and the mean relative deviation modulus $(\mathrm{P})(\mathrm{P}<10 \%$, except for the adsorption of peel that did not show adjustment to meet this standard, thus, $\mathrm{P}<15 \%$ was adopted) (Table 4 ), GAB equation was the only model able to predict, with good precision, the adsorption and desorption isotherms of the three parts of buriti under the conditions studied. The GAB model has shown to be versatile in predicting isotherms of products with different chemical compositions, from both plant and animal origin (MAROULIS et al., 1988; PRADO et al., 1999; PARK; BIN; BROD, 2001; GUERRA; NEVES; PENA, 2005; ASSUNÇÃO; PENA, 2007; SILVA; SILVA; PENA, 2008).
Table 4. Model parameters adjustments to the adsorption and desorption data of buriti fruit parts.

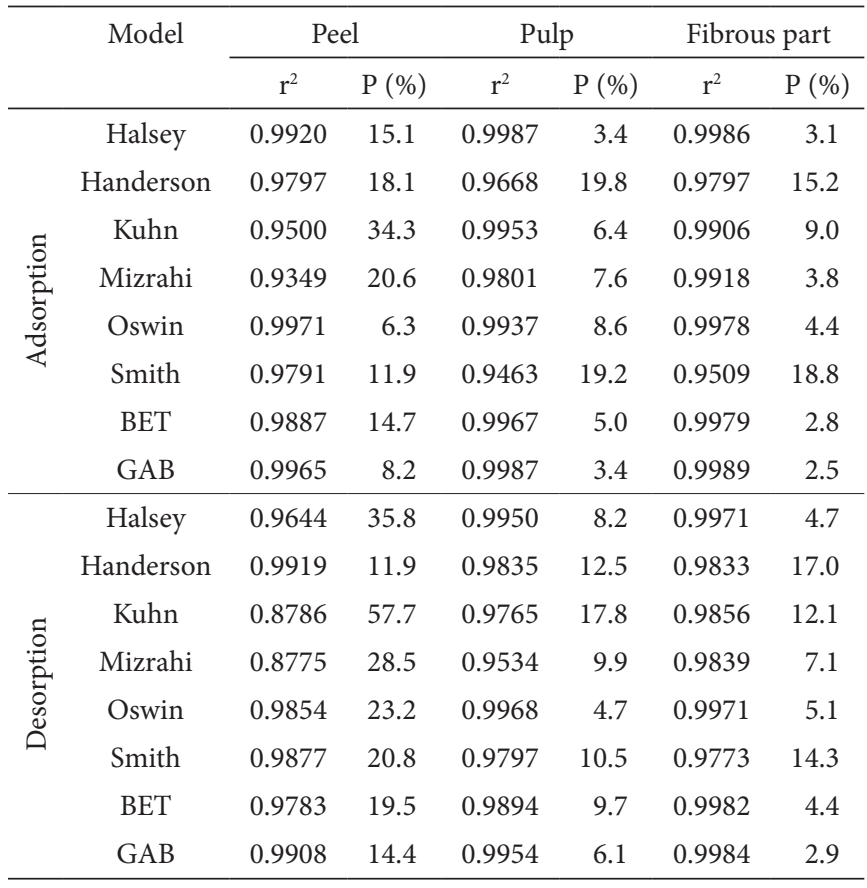

$\mathrm{r}^{2}$ - Determination coefficients and $\mathrm{P}-$ mean relative deviation modulus.

\section{Conclusions}

One-fifth of the dietary fiber of buriti pulp is soluble and $68 \%$ of the total fat is unsaturated, which qualifies it as potential for use in human consumption.

The peel, pulp, and fibrous part of buriti will be microbiologically stable at $25{ }^{\circ} \mathrm{C}$, if they present moisture content below 8.5, 7.3, and $11.0 \mathrm{~g} \mathrm{H}_{2} \mathrm{O} .100 \mathrm{~g}^{-1} \mathrm{~d}$.m., respectively.

For better conservation, the dried peel, pulp, and fibrous part of buriti should be packed in low water vapor permeability package.

According to the monolayer moisture content of the peel, pulp, and fibrous part of the buriti, the drying process of these parts should not reach moisture level lower than 5.9, 5.0, and $6.4 \mathrm{~g} \mathrm{H}_{2} \mathrm{O} .100 \mathrm{~g}^{-1}$ d.m., respectively.

The GAB model can be used with very good accuracy to predict the adsorption and desorption isotherms of the peel, pulp, and fibrous part of buriti.

\section{Acknowledgements}

The authors are grateful for the financial support provided by the Research Foundation of the State of Pará (FAPESPAProcess 058/2008) and to The National Council for Scientific and Technological Development (CNPq -Process 620209/2008-9).

\section{References}

ALBUQUERQUE, M. L. S. et al. Infrared absorption spectra of Buriti (Mauritia flexuosa L.) oil. Vibrational Spectroscopy, v. 33, n. 1, p. 127-131, 2003. http://dx.doi.org/10.1016/S0924-2031(03)00098-5 
AMERICAN OIL CHEMISTS' SOCIETY - AOCS. Official Methods and recommended practices of the American Oil Chemists' Society". 5. ed. Champaign: AOCS, 2002.

ASSOCIATION OF OFFICIAL ANALYTICAL CHEMISTS AOAC. Official methods of Analysis. 16. ed. Gaithersburg: AOAC, 1997. 1298 p.

ASSUNÇÃO, A. B.; PENA, R. S. Comportamento higroscópico do resíduo seco de camarão-rosa. Ciência e Tecnologia de Alimentos, v. 27, n. 4, p. 786-793, 2007.

AVIARAA, N. A. et al. Moisture sorption isotherms of sorghum malt at 40 and $50^{\circ} \mathrm{C}$. Journal of Stored Products Research, v. 42, n. 3, p. 290-301, 2006.

BRAZIL. Agência Nacional de Vigilância Sanitária. Portaria nº 27, de 13 de janeiro de 1998. Regulamento Técnico referente à Informação Nutricional Complementar. Diário Oficial da República Federativa do Brazil, Brasília, DF, 16 jan. 1998.

BRAZIL. Agência Nacional de Vigilância Sanitária. Resolução RDC $n^{\circ} 263$, de 22 de setembro de 2005. Regulamento técnico para produtos de cereais, amidos, farinhas e farelos. Diário Oficial da República Federativa do Brazil, Brasília, DF, 23 set. 2005.

CHIRIFE, J.; IGLESIAS, H. A. Equations for fitting water sorption isotherms of foods: Part 1 - a review. Journal of Food Technology, v. 13, n. 2, p. 159-174, 1978.

CLEMENT, C. R.; AGUIAR, J. P. L.; ARKCOLL, D. B. Composição química do mesocarpo e do óleo de três populações de pupunha (Bactris gasipaes) do Rio Solimões, Amazonas, Brazil. Revista Brasileira de Fruticultura, v. 20, n. 1, p. 115-118, 1998.

DE ROSSO, V. V.; MERCADANTE, A. Z. Identification and quantification of carotenoids, by HPLC-PDA-MS/MS, from Amazonian fruits. Journal of Agricultural and Food Chemistry, v. 55, n. 13, p. 5062-5072, 2007. PMid:17530774. http://dx.doi. org/10.1021/jf0705421

FERREIRA, E. L. Manual of the palms of Acre, Brazil. Instituto Nacional de Pesquisas, Universidade Federal do Acre. Disponível em: <http://www.nybg.org/bsci/acre/www1/manual_palmeiras. html $>$. Acesso em: 16 jan. 2010.

FIGUEROLA, F. et al. Fiber concentrates from apple pomace and citrus peel as potential fibers sources for food enrichment. Food Chemistry, v. 91, n. 3, p. 395-401, 2005. http://dx.doi.org/10.1016/j. foodchem.2004.04.036

GAZEL-FILHO, A. B. G.; LIMA, J. A. S. O Buritizeiro (Mauritia flexuosa) e seu potencial de utilização. Macapá: EMBRAPA, 2001.
FURMANIAK, S. et al. Applicability of the generalised D'Arcy and Watt model to description of water sorption on pineapple and other foodstuffs. Journal of Food Engineering, v. 79, n. 2, p. 718-723, 2007. http://dx.doi.org/10.1016/j.jfoodeng.2006.02.036

GUEDES, A. M. M. Caracterização Estudo da Extração do óleo da polpa de Tucumã por $\mathrm{CO}_{2}$ supercrítico. 2006. 78 f. Dissertação (Mestrado em Ciência e Tecnologia de Alimentos)-Universidade Federal do Pará, Belém, 2006.

GUERRA, R. B.; NEVES, E. C.; PENA, R. S. Caracterização e processamento de leite bubalino em pó em secador por nebulização. Ciência e Tecnologia de Alimentos, v. 25, n. 3, p. 443-447, 2005. http://dx.doi.org/10.1590/S0101-20612005000300009

MAROULIS, Z. B. et al.. Application of the GAB model to the sorption isotherms for dried fruits. Journal of Food Engineering, v. 7, n. 1, p. 63-70, 1988. http://dx.doi.org/10.1016/0260-8774(88)90069-6

PARK, K. J.; BIN, A.; BROD, F. P. R. Obtenção das isotermas de sorção e modelagem matemática para a Pêra (Bertlett Pyrus sp.) com e sem desidratação osmótica. Ciência e Tecnologia de Alimentos, v. 21 , n. 1, p. 73-77, 2001. http://dx.doi.org/10.1590/S010120612001000100016

PARK, K. J.; NOGUEIRA, R. I. Modelos para ajuste de isotermas de sorção de alimentos. Engenharia Rural, v. 3, n. 1, p. 80-6, 1992.

PENG, G. et al. Modeling of water sorption isotherm for corn starch. Journal of Food Engineering, v. 80, n. 2, p. 562-567, 2007. http:// dx.doi.org/10.1016/j.jfoodeng.2006.04.063

PRADO, M. E. T. et al. Isotermas de sorção de Tâmaras: determinação experimental e avaliação de modelos matemáticos. Ciência e Tecnologia de Alimentos, v. 19, n. 1, p. 143-146, 1999. http://dx.doi. org/10.1590/S0101-20611999000100026

SALWIN, H. Defining minimum moisture contents for dehydrated foods. Food Technology, v. 13, p. 594-585, 1959.

SALWIN, H. Moisture levels required for stability in dehydrated foods. Food Technology, v. 17, n. 9, p. 1114-1121, 1963.

SCOTT, W. J. Water relations of food spoilage microorganisms. Advents Food Research, v. 7, n. 9, p. 83-127, 1957.

SILVA, A. E.; SILVA, L. H. M.; PENA, R. S. Comportamento higroscópico do açaí e cupuaçu em pó. Ciência e Tecnologia de Alimentos, v. 28, n. 4, p. 895-901, 2008. http://dx.doi.org/10.1590/ S0101-20612008000400020

SILVA, S. M. et al. Characterization of oil extracted from buriti fruit (Mauritia flexuosa) grown in the Brazilian Amazon Region. Journal of the American Oil Chemists' Society, v. 86, n. 7, p. 611-616, 2009.

STATSOFT. Statistica Kernel Release 7.1. Computer program manual. Tulsa: StatSoft, Inc., 2006. 